УДК 316.625+17.022.1]:005.25

DOI https://doi.org/10.32837/apfs.v0i27.925

I. M. Вітковська

ORCID ID: https://orcid.org/0000-0001-5624-4301

старша викладачка кафедри соиіології управління та соціальної роботи Харківського національного університету імені В. Н. Каразіна

I. A. Свдокимова
ORCID ID: https://orcid.org/0000-0001-7099-757X
кандидатка соиіологічних наук, доцентка,
в. о. завідувача кафедри соціологї̈ управління та соціальної роботи
Харківського національного університету імені В. Н. Каразіна

\title{
СТАНОВЛЕННЯ ПОНЯТТЯ ВІДПОВІДАЛЬНОСТІ У ФІЛОСОФІї ТА СОЦІОЛОГІї
}

Поняття відповідальності є популярним у сучасному політичному, науковому, правовому та повсякденному дискурсі в Україні. Досить поширеними є заклики до громадян, соціальних груп та інститутів, організацій, держави бути відповідальними. При цьому вимога здійснення відповідальної діяльності кожним з перелічених акторів виглядає аксіоматично та $є$ безперечно актуальною для українського суспільства в умовах загострення багатьох соціально-економічних, політичних, культурних проблем та нестабільного розвитку. Водночас одна з проблем, яка виникає на шляху її втілення, полягає, на наш погляд, у відсутності чіткого розуміння того, чим є відповідальна діяльність, в іноді нетолерантному ставленні до ії інакшого, ніж власне, розуміння, тому звернення уваги політиків та громадськості на особливості аналізу цього феномена 3 боку науковців, зокрема філософів та соціологів, $\mathrm{e}$, на наш погляд, актуальним завданням.

Вивченню поняття відповідальності як філософсько-соціологічного феномена присвячена значна кількість наукових досліджень. Проблема відповідальності завжди перебувала в полі зору тих учених, які паралельно займалися дослідженням соціальних, політичних, економічних питань функціонування соціуму, зокрема Платона, Аристотеля, П. Гольбаха, К. Гельвеція, І. Канта, І. Фіхте, Ф. Гегеля, Т. Гобса, Дж. Локка, Д. Юма, Дж.С. Мілля, ЖЖ.-П. Сартра, ЖЖ.-Ж. Руссо, Ф. Ніцше, М. Вебера, Г. Йонаса, К.-О. Апеля, М. Ріделя, Ю. Габермаса, Т. Парсонса, Е. Дюркгейма, В. Ядова, Дж. Ролза, П. Рікера, К. Маркса, О. Плахотного, С. Кьєркегора, Е. Левінаса.

Мета статті полягає у визначенні головних етапів становлення поняття відповідальності у філософії та соціології, з'ясуванні особливостей розуміння відповідальності на кожному з них.

Формування поняття відповідальності відбувається ще в античний період у працях Платона й Аристотеля. Саме Платон одним із перших розглянув питання про відповідальність людини за свої вчинки, намагався пояснити причини вчин- ків людини через призму співвідношення добровільного та примусового, свідомого та несвідомого, об'єктивного та суб'єктивного, вільного та необхідного. Відповідальність людини за власний вибір як результат свободи вибору є очевидною для Платона [11, с. 447-453]. Заслуга Платона полягає в тому, що він охарактеризував взаємозв'язок між відповідальністю людини та ії свободою, а також вбачав відповідальність особи у виконанні/ невиконанні покладених на неї обов'язків.

Вагомий внесок у розгляд проблеми відповідальності зробив автор етичного твору «Нікомахова етика» Аристотель. Філософ визначав етику практичною наукою, метою якої є навчання доброчесності. Аристотель побудував теорію етики, в основі якої лежить виховання доброчесного, відповідального громадянина, без якого неможливе функціонування держави з її позитивними формами правління, а саме монархії, аристократії та політії. Філософ впевнений, що лише повна свобода вибору, яка супроводжується виваженням цілей та засобів, є умовою відповідальності людини за свої вчинки [2, с. 99], тобто саме в античний період зароджується розуміння відповідальності як внутрішньої якості особистості, доброчесного та відповідального громадянина.

У післяаристотелівський період моральність індивіда відокремлюється від його державного й політичного життя, що відповідним чином відбивається на розумінні відповідальності людини перед суспільством і перед власною совістю.

У період зародження християнської ідеології, яка припадає на період загальносуспільної кризи, котра охопила Римську імперію, поняття відповідальності починає ототожнюватися 3 поняттям християнської відповідальності. У рамках концепції християнства (у період появи «Нового завіту», середина-кінець I століття н.е.) виникає релігійна ідея особистої відповідальності людини перед Богом. Новий Завіт має священний характер, а проповіді Христа та апостолів дають нам уявлення про абсолютну відповідальність людини 
за її гріхи, тобто відповідальність людини полягає в покірності Господу та відданому йому служінню.

Умовним початком періоду Середньовіччя вважається 476 рік - рік падіння Римської імперії. Цей період охоплює величезний тисячолітній період історії з II століття до XV століття, що характеризується розвитком феодального суспільства з пануванням релігії та церкви у всіх сферах суспільного життя, тому поняття відповідальності продовжує ототожнюватися 3 поняттям християнської відповідальності.

Більш глибоке теоретичне обгрунтування поняття відповідальності відбувається протягом XVII століття, тобто в період становлення філософiї Нового часу. Основні ідеї цього періоду представлені у працях західноєвропейських філософів Т. Гоббса, Дж. Локка, Д. Юма, ЖЖ.-Жћ. Руссо.

Т. Гоббс розглядав питання відповідальності влади та відповідальності громадян за недотримання ними законів. Як вважав Т. Гоббс, громадянські закони - це результат суспільного договору, які означають, що, втрачаючи частину природної свободи, громадяни набувають умов для добробуту, але, на жаль, вони стають підзвітними. Підзвітність Т. Гоббс розумів як «політичну відповідальність особи перед державою» [4]. Дж. Локк був переконаний у тому, що відповідальність особи й суспільства виходить із природного стану суспільства. Як писав філософ, «відповідальність - це стан свободи, а не стан свавілля. Обмежує свободу людини природний закон, тобто відповідальність» [18, с. 9]. У рамках теорії суспільного договору до теми відповідальності звертався Ж.-ЖЖ. Руссо, який у своїх працях осмислював «політичний організм» як угоду між народом та правителями, яка передбачає взаємну відповідальність держави та громадян [6, с. 25]. Таким чином, на думку західноєвропейських філософів Нового часу, поняття відповідальності співвідноситься зі свободою, але свобода людини не абсолютна, вона співвідноситься з відповідальним вибором. Відповідальність людини визначається як необхідна умова співжиття у суспільстві.

Загострення проблеми відповідальності спостерігається в період Просвітництва XVIII століття у Франції. Видатні представники французького просвітництва - Гольбах, Гельвецій, Дідро - заперечують можливість людської свободи, доводячи обумовленість волі людини мотивами, обставинами або станом людського організму. Людина для французьких матеріалістів є дитям природи, тому, подібно до природи, як людина, так і суспільство, дотримуються однакових законів. Все, що трапляється, має сприйматися людиною як належне. У такому ракурсі, звісно, питання відповідальності втрачає свій сенс.

$\mathrm{У}$ другій половині XVIII століття центр європейської філософської думки перемістився 3
Англії та Франції в Німеччину. Цей період отримав назву періоду класичної німецької філософії. Одним із перших, хто акцентував увагу на поняттях «відповідальний» та «відповідальність», був I. Кант. Учений за допомогою таких термінів, як «воля», «свобода», «категоричний імператив», «моральний закон», трактував це поняття як форму самоконтролю, відповідальність людини за власні вчинки. I. Кант зазначав, що «моральний закон» втілюється в людській совісті: «совість $€$ внутрішнім суддею над усіма вільними вчинками $<$...> совість повинна мислитися як суб'єктивний принцип відповідальності перед Богом за свої вчинки; поняття ж відповідальності поєднує вільну дію людини й закон» [8]. Зазначимо, що совість не завжди та не у всіх може гарантувати дотримання принципу відповідальності, тому I. Кант розвиває своє вчення про обов'язок. Як пише філософ, «саме це внутрішне добровільне прийняття обов'язку та перетворення його в принцип свідомої доброї волі й складає момент відповідальності» [8]. На думку I. Канта, відповідальність передбачає зрілість, «мужність керуватися власним розумом».

Значну увагу проблемі відповідальності приділили вчені кінця XIX - початку XX століття, перш за все $Ф$. Ніцше та М. Вебер. Варто зазначити, що саме Ф. Ніцше та М. Вебер сформулювали найважливіші підходи до розуміння поняття відповідальності та її основних принципів, хоча їхні погляди дещо різнилися. Ф. Ніцше розглядав відповідальність як інстинкт, який називається «сумління». Для Ф. Ніцше поняття «відповідальність» та «сумління» - синоніми. Відповідальність розглядалася автором як внутрішня характеристика особистості. М. Вебер визначав відповідальність як соціально-політичний регулятор діяльності. На його думку, будь-яка етична дія може бути орієнтована або на «етику переконання», або на «етику відповідальності». Етика переконання - це абсолютна етика, спрямована до досконалості; такою $€$ релігійна етика в ії суворих визначеннях. Етика відповідальності - це етика практичної діяльності, орієнтованої на об'єктивні результати, яка вимагає обов'язкового врахування наслідків своїх дій під час прийняття певного рішення [3, с. 645].

Сучасний період дослідження поняття відповідальності характеризується поверненням до ідеї «етики відповідальності» М. Вебера, яка знаходить своє продовження у праці Г. Йонаса «Принцип відповідальності» [7] та у роботах представників дискурсивно-комунікативного та феноменологічного підходів.

Американсько-німецький науковець Г. Йонас, дослідивши теоретичні варіанти етики відповідальності перед майбутнім, розробив концепцію відповідальності, у якій зосередив увагу на техногенній небезпеці, що загрожує суспільству. 
За твердженням Г. Йонаса, відповідальність - це етична категорія, спрямована у майбутне та проголошена найвищою моральною цінністю XXI століття. Як зазначає вчений, в умовах глобалізації на зміну «людині розумній» має прийти «людина відповідальна» [7, с. 26]. Представники дискурсивно-комунікативного підходу (К.-О. Апель, М. Рідель, Ю. Габермас) підтримують ідеї етики відповідальності й доводять необхідність дискурсивного обгрунтування норм відповідальної поведінки [13, с. 68-83]. Так, наприклад, К.-О. Апель у роботі «Дискурс і відповідальність. Проблема переходу до постконвенційної моралі» [1] розмірковував про етику дискурсу, як про етику відповідальності. На думку К.-О. Апеля, «відповідальність - це практичний дискурс, у якому норми обгрунтовуються відповідно до ситуацій, залежно від їхньої необхідності».

Інституціональний підхід до аналізу сутності феномена відповідальності розвивали Т. Парсонс, Е. Дюркгейм, М. Вебер, В. Ядов та інші вчені. За цього підходу саме відповідальність зможе забезпечити суспільну стабільність шляхом закріплення норм та правил взаємовідносин у суспільстві. Сучасними прихильниками інституційного підходу є Дж. Ролз, П. Рікер та інші науковці.

Сучасний американський науковець Джон Ролз є автором «дистрибутивної теорії соціальної справедливості». Він осучаснив і розширив ідеї I. Канта щодо проблеми відповідальності та співвідніс іï з поняттям соціальної справедливості. У теорії справедливості Дж. Ролза справедливим вважається те суспільство, у якому економічна нерівність сприяє досягненню більш високого рівня життя найбідніших членів суспільства. Таке розуміння окреслює концепт справедливості як критерій результатів людських вчинків (принесли вони користь суспільству чи шкоду?). Справедливість як моральний принцип відповідальності у Дж. Ролза має обов'язковий атрибут публічності. На думку вченого, відповідальністю наділяються апріорі всі соціальні інституції (жоден соціальний інститут не засновується для нанесення шкоди суспільству, а лише навпаки - задля соціальної корисності) [15, с. 91-92]. Отже, Дж. Ролз, на відміну від Г. Йонаса, вважає, що індивід має нести відповідальність не лише за природу, але й за справедливий характер людських взаємовідносин, за реалізацію принципів справедливості в суспільстві та виводить на передній план моральний принцип відповідальності, який має обов'язковий характер у діяльності соціальних інститутів.

Французький філософ Поль Рікер здійснив грунтовний внесок у теорію відповідальності, яку виклав у праці «Право і справедливість» [14]. Слідом за Дж. Ролзом дослідник розподіляє відповідальність на дві складові частини, а саме юридичну, або чітко визначену, та моральну, або розпливчасту [14, с. 42]. При цьому П. Рікер наголошує на тому, що в сучасному світі відбувається певний перегляд юридичної складової частини відповідальності й зазначає, що сучасне розуміння відповідальності переважно зміщується 3 юридичного в моральний бік. Розглядаючи триєдність «повноваження - шкода - відповідальність», П. Рікер доходить розуміння пріоритету відповідальності найвищих посадових осіб перед суспільством, оскільки чим більшим є повноваження, тим більшим є ризик заподіяння шкоди суспільству, отже, тим більшою має бути персональна відповідальність особи [14, с. 56].

Іншої точки зору під час аналізу сутності феномена відповідальності дотримувалися вчені-марксисти (основними представниками є К. Маркс, Ф. Енгельс). Марксистська концепція відповідальності грунтується на основі єдності двох проблем, а саме теорії свободи та проблеми взаємовідносин між особистістю та суспільством. Представники цього підходу визначають відповідальність як «універсальну форму зв'язку та взаємозалежності особистості та суспільства» [12]. Заслуга марксизму - це перш за все розуміння індивіда як істоти суспільної, яка не може жити ізольовано від інших поза соціально-економічними відносинами. Описуючи класово антагоністичне суспільство, К. Маркс наділяв усі відносини в суспільстві класовими характеристиками. Вважаємо, що відповідальність також можна описати як явище, що має класовий характер. Згідно зі вченням К. Маркса, клас буржуазії прагнув укріпити капіталістичні відносини, отже, відповідав за добробут свого класу, але ніяким чином не відповідав перед робітничим класом (пролетаріатом). Крізь призму політико-економічних ідей, викладених у праці К. Маркса «Капітал», у завуальованому вигляді ми знаходимо ідею відповідальності пролетаріату за побудову комуністичного суспільства: «як клас, який повинен здійснити всесвітньо-історичну місію знищення капіталізму та побудови нового, комуністичного суспільства, пролетаріат і сприймає свою відповідальність, насамперед, як відповідальність за досягнення цієї мети" [10].

Зазначимо, що марксистська концепція відповідальності успішно продовжувала розроблялася Харківською школою під керівництвом О. Плахотного в 70-80-ті роки XX століття. У працях О. Плахотного, насамперед у монографії «Проблеми соціальної відповідальності» [12], зазначається, що одним з основних принципів, які характеризують марксистський підхід до проблеми відповідальності, є єдність гносеологічного та соціологічного аспектів у їі дослідженні. Дослідження відповідальності у гносеологічному аспекті пояснює її як специфічний прояв матеріальних відносин, соціального буття. Соціологічний підхід потребує насамперед виявлення місця та 
ролі відповідальності в системі суспільних явищ та суспільної регуляції.

Екзистенціалізм як одна з найвпливовіших течій XIX - XX століть відкриває перед нами своєрідний погляд на проблему відповідальності, адже тема відповідальності була й залишається однією з найулюбленіших у дискурсі екзистенціалістів. Екзистенціалісти (відомими представниками $є$ С. Кьєркегор, Жан-Поль Сартр) відповідальність розглядали не як відповідальність особи перед суспільством або суспільства перед особою, а як загальний рівень розвитку відповідальних відносин у суспільстві в його індивідуалізованому вигляді. С. Кьєркегор пов'язував та співвідносив свободу не $з$ обов'язками, а з відповідальністю. Свобода виражається у відповідальності, причому йдеться про відповідальність у новому її значенні, а саме осмисленому ставленні до власної поведінки незалежно від інститутів чи категоричних настанов. Жан-Поль Сартр також вважає, що відповідальність повністю суб'єктивна. Усі вчинки людини визначаються самою людиною, а не обумовлені середовищем, спадковістю чи вихованням, тому відповідальність лягає на саму людину. Людина відповідальна за свій вибір і за те, що вона вибирає: існування у світі речей, комфорті та несвободі або життя як прояв свого єства незалежно від розвитку суспільства й культури. Таку відповідальність французький екзистенціаліст називає «абсолютною» [17]. Таким чином, екзистенціалісти $€$ прихильниками особисто-орієнтованої концепції відповідальності у якій повна відповідальність за своє існування покладається на людину.

Сучасний представник феноменологічного підходу Е. Левінас продовжував розвивати ідеї етичної концепції відповідальності. У центрі етичної концепції вченого перебуває проблема моральної відповідальності особи перед власним «Я», перед «Іншими» та перед Богом. Зазначимо, що Е. Левінас критикував екзистенціалізм, особливо концепцію суб'єктивної відповідальності «для себе» Ж.-П. Сартра, натомість обгрунтував концепцію «відповідальності за Іншого», яка, на його думку, є стрижнем суб'єктивності. Е. Левінас запропонував теорію, у якій обгрунтував сутність персональної етичної відповідальності перед іншими. На його думку, моральне ставлення до «Іншого» та до себе самого є відповідальністю. Від кожного окремого індивіда залежить можливість побудови відповідального суспільства [5, с. 8].

Підсумовуючи, зазначимо, що відповідальність як суспільне явище має тривалу історію становлення й розвитку. Систематизувавши основні трактування поняття відповідальності залежно від етапів суспільного розвитку, ми виявили, що в античний період зароджується розуміння відповідальності як внутрішньої якості особистості, що близьке до поняття обов'язку, за невиконання якого людину чекало покарання (Платон, Аристотель). В період Середньовіччя поняття відповідальності починає ототожнюватися 3 поняттям християнської відповідальності, насамперед як відповідальність перед Богом, дотримання якої пов'язане з виконанням відповідних релігійно-моральних приписів. Західноєвропейська філософія Нового часу характеризується переходом від розуміння відповідальності як зовнішнього механізму контролю (Т. Гоббс, Дж. Локк) до трактування iï як форми самоконтролю (І. Кант, Г. Гегель). Період із кінця XIX - початку XXI століття можемо охарактеризувати як найбільш динамічний щодо вивчення поняття відповідальності, що характеризується утвердженням плюралізму поглядів на проблему відповідальності. Від ідеї «етики відповідальності» М. Вебера та його сучасних послідовників, таких як Г. Йонас, М. Рідель, Ю. Габермас, К.-О. Апель, які розглядають відповідальність як етичну категорію, у якій перехрещуються мовні та реальні відносини особи, що виражається у співвідповідальності усіх членів комунікативної спільноти, до інституціонального підходу (Т. Парсонс, Е. Дюркгейм, М. Вебер, В. Ядов, Дж. Ролз, П. Рікер), де відповідальність має обов'язковий характер у діяльності всіх соціальних інститутів. Від марксистського підходу (К. Маркс, Ф. Енгельс), де суспільство важливіше індивіда, а відповідальність повинна бути колективною, до екзистенціального (С. Кьєркегор, Ж.-П. Сартр), де відповідальність розглядається повністю в індивідуалізованому вигляді.

\section{Jimepamypa}

1. Апель К.-О. Дискурс і відповідальність: проблема переходу до постконвенціональної моралі / пер. 3 нім. В. Купліна. Київ, 2009. 430 с.

2. Аристотель. Нікомахова етика / пер. В. Ставнюка. Київ : Аквілон-Плюс, 2002. 480 с.

3. Вебер М. Политика как призвание и профессия. Избранные произведения. Москва : Прогресс, $1990.696 \mathrm{c}$.

4. Гобс Т. Левиафан или материя, форма и власть государства церковного и гражданского. Москва : Мысль, 1991. 36 с.

5. Гринчишина Н. Моральна відповідальність особи в етичній концепції Емануеля Левінаса : автореф. дис. ... канд. філософ. наук : спец. 09.00.07 «Етика»; КНУ ім. Т. Шевченка. Київ, 2009. 14 с.

6. Грищук В. Соціальна відповідальність : навчальний посібник. Львів : ЛДУВС, 2012. 151 с.

7. Йонас Г. Принцип відповідальності. У пошуках етики для технологічної цивілізації. Київ : Лібра, 2001. 400 c.

8. Кант И. Основы метафизики нравственности. Сочинения : в 6 т. Т 4. Москва : Мысль, 1965. 378 с.

9. Кьеркегор С. Наслаждение и долг. Ростов-на Дону : Феникс, 1998. 415 с.

10. Маркс К. Теории прибавочной стоимости (IV том «Капитала»). Ч. 1. Москва : Политиздат, 1978. 476 с. 
11. Платон. Государство. Сочинения : в 3 т. Москва : Мысль, 1991. Т. 1.860 с.

12. Плахотный А. Проблема социальной ответственности (Социологический аспект проблемы). Харьков : Высшая школа, 1981. 256 с.

13. Рідель М. Свобода і відповідальність. Першоджерела комунікативної філософії. Київ : Либідь, 1996. С. $68-83$.

14. Рікер П. Право і справедливість / пер. із фр. Київ, 2002. 216 с.

15. Ролз Дж. Теорія справедливості / пер. з англ. О. Мокровольський. Київ : Видавництво Соломії Павличко «Основи», 2001. 822 с.

16. Савченко I., Радченко О. Ціннісний вимір соціальної відповідальності в демократичній державі : монографія. Харків : ХНУВС, 2008. 200 с.

17. Сартр Ж.-П. Бытие и ничто: Опыт феноменологической онтологии. Москва : Республика, 2000. 639 с.

18. Шаповал В. Соціальна відповідальність бізнесу у структурі управління економікою : монографія. Дніпропетровськ : НГУ, 2011. 356 с.

\section{Анотація}

Вітковська I. М., Свдокимова I. А. Становлення поняття відповідальності у філософії та соціології. Стаття.

Стаття присвячена аналізу етапів становлення поняття відповідальності у філософії та соціології та з’ясуванню особливостей розуміння відповідальності на кожному з них.

Зроблено висновок, що відповідальність як суспільне явище має тривалу історію становлення й розвитку. У статті систематизовано основні трактування поняття відповідальності залежно від етапів суспільного розвитку. Зроблено висновок, що в античний період зароджується розуміння відповідальності як внутрішньої якості особистості, що близьке до поняття обов'язку, за невиконання якого на людину чекало покарання (Платон, Аристотель). В період Середньовіччя поняття «відповідальності» починає ототожнюватися з поняттям відповідальності перед Богом. Період Нового часу характеризується переходом від розуміння відповідальності як зовнішнього механізму контролю (Т. Гоббс, Дж. Локк) до iï трактування як форми самоконтролю (I. Кант, Г. Гегель). Період із кінця XIX - початку XXI століття $€$ найбільш динамічним щодо вивчення поняття відповідальності та характеризується утвердженням плюралізму поглядів на проблему відповідальності.

У статті докладно проаналізовано сучасні концепції відповідальності, зокрема ідеї етичної концепції відповідальності М. Вебера та його сучасних послідовників (Г. Йонас, М. Рідель, Ю. Габермас, К.-О. Апель), які розглядають відповідальність як етичну категорію, у якій перехрещуються мовні та реальні відносини особи, що виражається у співвідповідальності усіх членів комунікативної спільноти. Значну увагу у статті приділено аналізу ідей інституціонального підходу до розуміння відповідальності (Т. Парсонс, Е. Дюркгейм, М. Вебер, В. Ядов, Дж. Ролз, П. Рікер), у межах якої відповідальність має обов'язковий характер щодо діяльності всіх соціальних інститутів. Зроблено огляд ідей марксистського підходу (К. Маркс, Ф. Енгельс), у якому наголошується на тому, що відповідальність має бути колективною. Розглянуто ідеї екзистенціального підходу, згідно з яким відповідальність розглядається як характеристика індивіда.

Ключові слова: відповідальність, відповідальність особистості, етика відповідальності, свобода, справедливість, соціологія, філософія.

\section{Summary}

Vitkovska I. M., Yevdokymova I. A. Formation of the concept of responsibility in philosophy and sociology. Article.

The article is devoted to the analysis of the stages of formation of the concept of responsibility in philosophy and sociology and to the elucidation of the peculiarities of the understanding of responsibility in each of them.

Itisconcluded thatresponsibilityasasocialphenomenon has a long history of formation and development. The article systematizes the main interpretations of the concept of "responsibility" depending on the stages of social development. It is concluded that in the ancient period there was an understanding of responsibility as an inner quality of the individual, which is close to the concept of duty, for non-fulfillment of which a person would be punished (Plato, Aristotle). During the Middle Ages, the concept of "responsibility" began to be identified with the concept of responsibility to God. The New Age period is characterized by the transition from the understanding of responsibility as an external mechanism of control (T. Hobbes, J. Locke) to its interpretation as a form of self-control (I. Kant, G. Hegel). The period from the end of XIX - beginning of XXI century is the most dynamic in the study of the concept of responsibility and is characterized by the assertion of pluralism of views on the problem of responsibility.

The article analyzes in detail the modern concepts of responsibility, in particular, the ideas of the ethical concept of responsibility of M. Weber and his modern followers (G. Jonas, M. Riedel, J. Habermas, K.-O. Appeal), who considers responsibility as an ethical category in which intersects linguistic and real relations, expressed in the responsibility of all members of the communicative community. Considerable attention in the article is paid to the analysis of ideas of the institutional approach to understanding of responsibility (T. Parsons, E. Durkheim, M. Weber, V. Yadov, J. Rawls, P. Reeker) within which responsibility has obligatory character concerning activity of all social institutions. An overview of the ideas of the Marxist approach (K. Marx, F. Engels), which emphasizes that responsibility must be collective. The ideas of the existential approach according to which responsibility is considered as the characteristic of the individual are considered.

Key words: responsibility, personal responsibility, ethics of responsibility, freedom, justice, sociology, philosophy. 